\title{
Studying the Influence of Static Converters' Current Harmonics on a PEM Fuel Cell using Bond Graph Modeling Technique
}

\author{
Wafa BEN SALEM ${ }^{1}$, Houssem CHAOUALI ${ }^{2}$, Dhia MZOUGHI and Abdelkader MAMI \\ UR-LAPER, UR17ES11, Faculty of Sciences of Tunis, University of Tunis El Manar, 2092 Tunis, Tunisia
}

\begin{abstract}
This paper shows the results of adding static converters (Boost, Buck and Buck-Boost converters) as an adaptation solution between a PEM Fuel Cell generator and a resistive load in order to study different effects of the converter on the generator performances in terms of voltage and current behavior. The presented results are obtained by simulating the Bond Graph developed model under 20-Sim software and show current and voltage behaviors with each converter under different scenarios of working conditions.
\end{abstract}

Keywords-Static converters; PEM Fuel Cell; boost; buck and buck-boost converters; bond graph; 20-Sim software

\section{INTRODUCTION}

In order to find a solution for the problem of energy production, new types of generators have been invented during these last years and are witnessing an important development and continuous evolution [1], [2].

Fuel Cells (FC) are basically used to convert hydrogen and oxygen into electricity. We can find various types of FCs nowadays such as Proton Exchange Membrane Fuel Cell (PEMFC) which are widely used in mobile applications such as electrical means of transportation [3], [4] but using these DC generators imposes the need of an adaptation method between the source and the load in order to get the best operating conditions of the system especially in the case of a variable power demand [5].

In order to study different electrical systems, several methods have been invented in order to model them. Among these approaches, we chose to use a graphical technique which is the Bond Graph (BG) modeling technique in order to simulate the dynamic behavior of the system [6], [7]. The benefit of this approach is that a complex electrical system for example can be designed as different subsystems, where each one presents one part of the real system, and then make the connection between the ports of these different subsystems in a form of bonds which describe the transfer of energy between the real parts of the system [8], [9].

In this context, this work proposes a study on current harmonics effects on a PEMFC when a static converter is used as an adaptation stage between it and the load. The most used static converters which are the Boost, Buck and Buck-Boost converters are studied. The Bond Graph approach is used to model the system and energy exchange between its different parts under the 20-Sim software which makes it possible to use the developed model to carry out different investigative simulations.

This paper is organized as follows:

- In Section II, Bond Graph approach is firstly presented along with PEMFC and the main three topologies of static converters. BG model of each component is also presented.

- Section III presents the obtained results of studying the interactions of the three static converters and the PEMFC. The influence of current harmonics, caused by addition static converters, on a PEM Fuel Cell is investigated.

\section{PRINCIPAL OF BOND GRAPH MODELING METHOD}

\section{A. General Over-view of Bond Graph Modeling Technique}

The bond graph tool is a graphical language confirmed as a structured approach to the modeling and simulation of multidisciplinary systems. This language allows building models of dynamic physical systems [10].

The energy exchanges in the bond graphs are represented by an arrow describing the direction of the transfer between two elements. This transfer is characterized by two variables: an effort and a flow whose product is equal to the power exchanged [11].

Table 1 summarizes the nine elements involved in the BG representation which are: the active elements (sources of effort and flow Se and Sf) which provide power, the passive elements which transform the power supplied to them into dissipated energy in the form of heat Element R) or stored (element $\mathrm{C}$ and I), the junction elements $(0,1, \mathrm{TF}, \mathrm{GY})$ which are conservative of power [12], [13].

TABLE. I. ELEMENTARY BRICKS OF A BOND GRAPH

\begin{tabular}{|c|c|c|}
\hline Symbol & Elements & Equations without causality \\
\hline $\mathbf{R}: \mathbf{r}$ & Resistance, friction & e-rf $=0$ \\
\hline$I: \mathbf{i}$ & Inductance, inertia & $\mathrm{e}-\mathrm{idf} / \mathrm{dt}=0$ \\
\hline$C: c$ & Capacity & $\mathrm{f}-\mathrm{cde} / \mathrm{dt}=0$ \\
\hline GY & Gyrator, MCC & $\mathrm{e} 1=\mathrm{rf} 2, \mathrm{e} 2=\mathrm{rf} 1$ \\
\hline TF & Transformer & $\mathrm{e} 1=\mathrm{ne} 2, \mathrm{f} 2=\mathrm{nf} 1$ \\
\hline Se & Effort Source & $\mathrm{e}=$ constant \\
\hline Mse & Controlled Effort Source & $\mathrm{e}=\mathrm{e}$ (input) \\
\hline Sf & Flow Source & $\mathrm{f}=$ constant \\
\hline Msf & Controlled Flow Source & $\mathrm{f}=\mathrm{f}$ (input) \\
\hline
\end{tabular}




\section{B. BG Model of PEMFC}

\section{1) Working Principle of the PEMFC}

The principle of the PEM stack consists of the oxidation of a fuel at the anode in order to release protons. These protons are conveyed via a proton conductor (electrolyte) to the cathode where the synthesis of the water. Fig. 1 shows the block diagram of a PEMFC type generator [14].

The operation of a fuel cell is described by a chemical relationship. This chemical reaction is an electrochemical oxidoreduction.

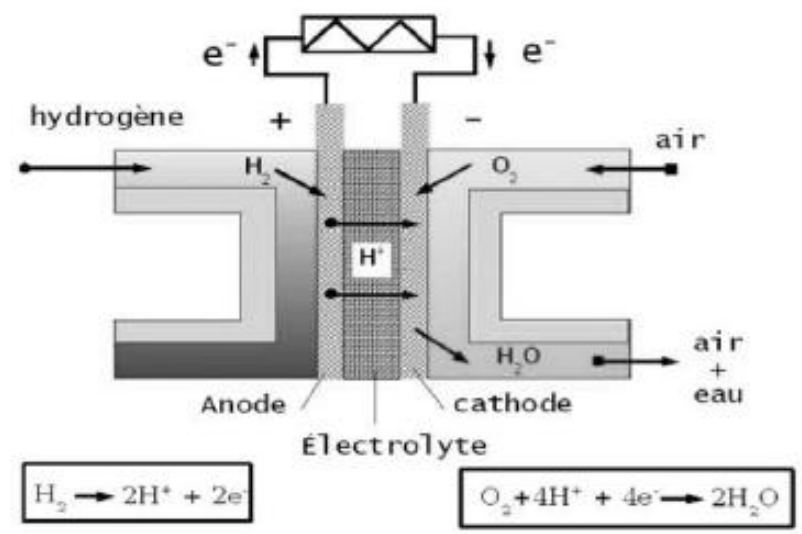

Fig. 1. Electrical presentation of a PV generator.

It reacts to hydrogen and oxygen to produce electricity, water and heat, depending on the overall chemical reaction given by (1).

$$
2 \mathrm{H} 2+02 \rightarrow 2 \mathrm{H} 2 \mathrm{O}+\text { electricity }+ \text { heat }
$$

This reaction takes place between the anode and the cathode which will be the electronic conductors, separated by a solid electrolyte which will be the proton conductor. More precisely, the reactions given by (2) and (3) occur at both electrodes.

At the anode: couple $\mathrm{H}+/ \mathrm{H} 2$ (Acid electrolyte):

$$
2 \mathrm{H} 2 \rightarrow 4 \mathrm{H}^{+}+4 \mathrm{e}^{-}
$$

At the cathode: couple $\mathrm{O} 2 / \mathrm{H} 2 \mathrm{O}$ :

$$
\mathrm{O} 2+4 \mathrm{H}^{+}+4 \mathrm{e}^{-} \rightarrow 2 \mathrm{H} 2 \mathrm{O}
$$

2) Bond Graph Model of PEMFC

Fig. 3 presents the BG model of the PEMFC which is composed of its three main parts: Anode, Electrolyte and Cathode.

Several information may be extracted from the V-I characteristic curve given in Fig. 2. First of all, the no-load voltage between is the voltage measured when the current is zero, so this first analysis is carried out without power generation.

We can talk then about three distinct areas of operation as detailed in Fig. 5 [15].

- The first zone is for the low intensities, it represents the anode and cathode activation surge.

- The second zone, which is linear and has a large range of current variation, characterizes the Ohmic behavior of the cell, it is the zone most used in operation.

- The third area related to diffusion limitation. This last zone must not be used in operation because the flooding deteriorates the performance of the battery very strongly.

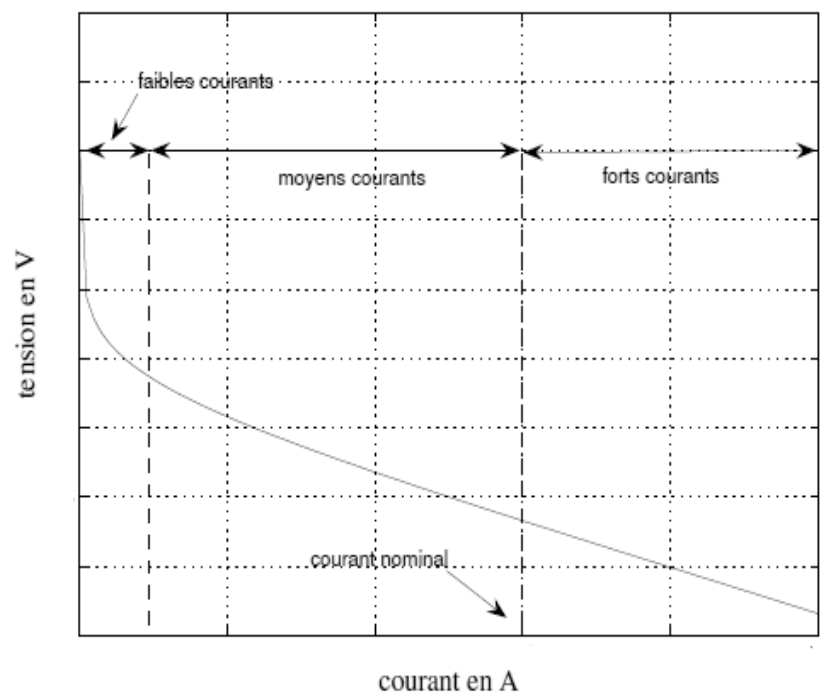

Fig. 2. Detailed V-I characteristic curve of the PEM fuel cell.

\section{BG Model of static converters}

\section{1) Boost Converter}

A boost converter allows increasing the output voltage supplied by the fuel cell by applying control signals to its parallel switch which is the basic component of the static converter [16].

For simulation in the 20-Sim environment, MTF represents a component that allows interrupting or authorizing the passage of a stream without obligation to distinguish what type it is.

Fig. 4 presents the BG model of the boost converter developed for simulation and Table 2 shows the parameters used in the developed BG model of the Boost Converter with causality assignment. 


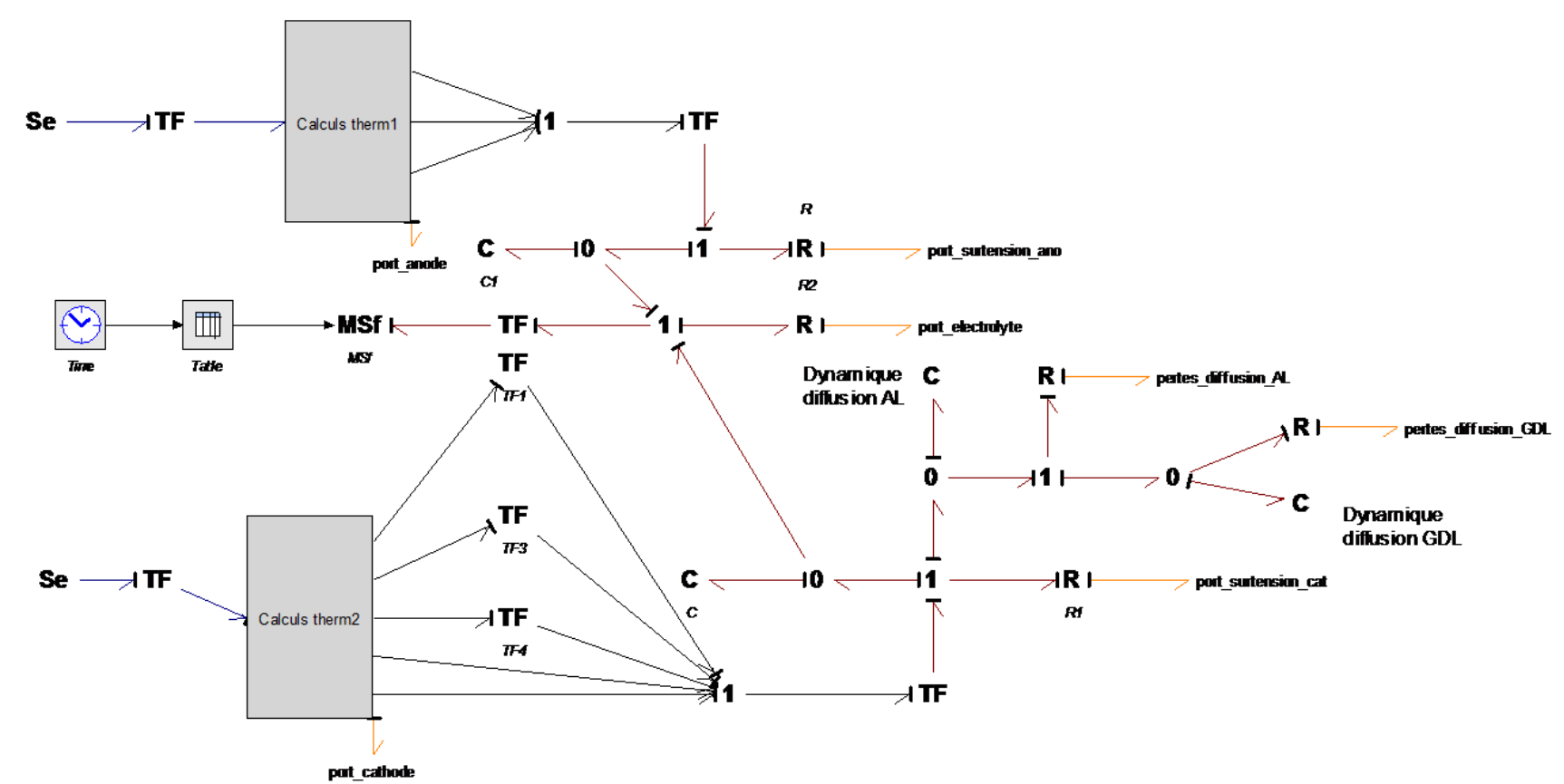

Fig. 3. BG model of the PEM fuel cell.

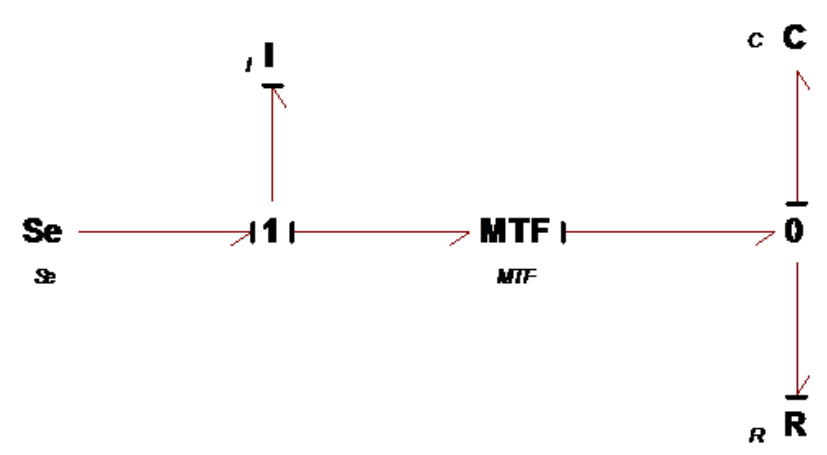

Fig. 4. BG model of the boost converter.

TABLE. II. PARAMETERS USED FOR THE BG MODEL OF BOOST CONVERTER

\begin{tabular}{|l|l|}
\hline Parameters & Values \\
\hline Resistance R & $10 \mathrm{ohm}$ \\
\hline Capacitance C & $0.002 \mathrm{~F}$ \\
\hline Inductance L & $0.000002 \mathrm{H}$ \\
\hline Voltage & $1 \mathrm{~V}$ \\
\hline
\end{tabular}

The boost operation realized by the boost converter is given by (4).

$$
\frac{\mathrm{V}_{0}}{\mathrm{~V}_{\mathrm{i}}}=\frac{1}{1-\alpha}
$$

Such That:

$\mathrm{V}_{\mathrm{o}}$ and $\mathrm{V}_{\mathrm{i}}$ : output and input voltages

$\alpha$ being the duty cycle. It represents the duration of the period T during which the switch conducts. $\alpha$ is between 0 and 1 .

In 20-Sim simulation environment, we fixed the duty cycle $\alpha=0.5$ and $\mathrm{Se}=1 \mathrm{~V}$. The obtained curves of the input and the output voltages of the converter in Fig. 5 show that steady state is reached at $\mathrm{t}=0.002 \mathrm{~s}$ and the output voltage is stable around $2 \mathrm{~V}$.

In (4), we can see that the output voltage is always higher than the input voltage (the output voltage increases with $\alpha$, and that theoretically it can be infinite when $\alpha$ approaches the value '1. That's why we talk about boosters.

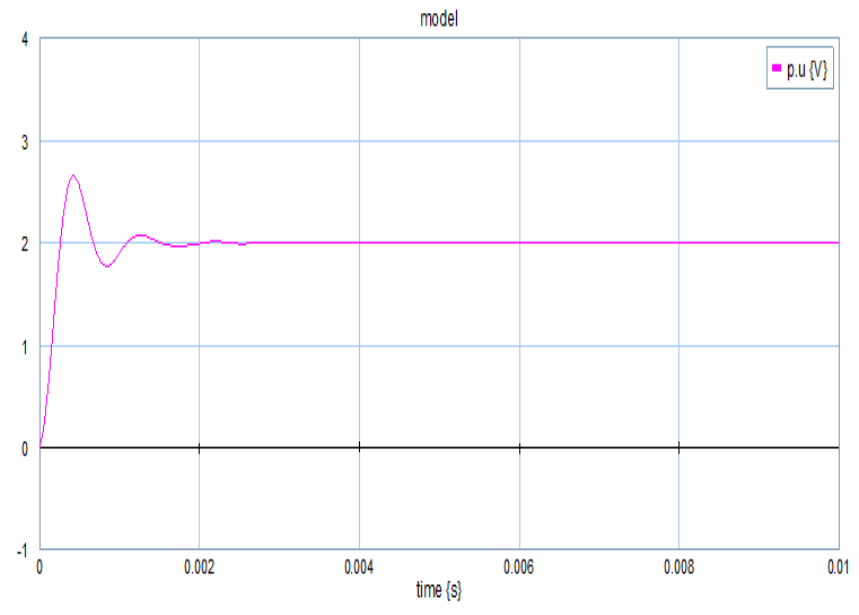

Fig. 5. Voltage at the terminals of the boost converter.

When a Boost converter operates in continuous conduction mode, the current flowing through the inductance never vanishes.

The characteristic describes the same evolution and the same behavior as that obtained by [17] as shown in Fig. 6. 


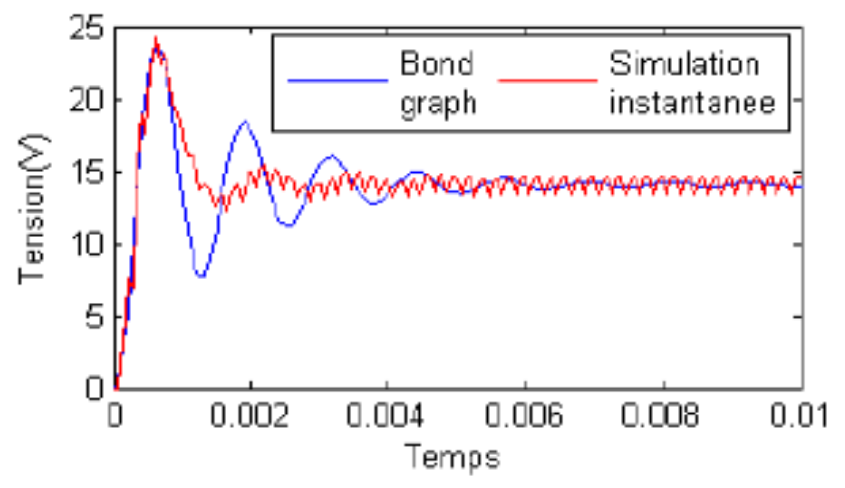

Fig. 6. Comparing BG simulation with real time simulation.

\section{2) Buck Converter}

A buck converter is used to reduce the voltage supplied by the fuel cell by applying control signals to its series electronic switch [16].

Its BG model with causality assignment that we developed is given in Fig. 7 where the different parameters that we used are presented in Table 3.

TABLE. III. PARAMETERS USED FOR THE BG MODEL OF BUCK CONVERTER

\begin{tabular}{|l|l|}
\hline Parametres & Values \\
\hline Resistance R & $1 \mathrm{ohm}$ \\
\hline Resistance R1 & $1 \mathrm{ohm}$ \\
\hline Resistance R2 & $0.01 \mathrm{ohm}$ \\
\hline Resistance R3 & $1 \mathrm{ohm}$ \\
\hline Capacitance C & $0.00010 \mathrm{~F}$ \\
\hline Inductance L & $0.000432 \mathrm{H}$ \\
\hline Voltage & $10 \mathrm{~V}$ \\
\hline
\end{tabular}

In continuous conduction, we the output voltage and current of a Buck converter are given by (5).

$\frac{\mathrm{V}_{\mathrm{o}}}{\mathrm{Vi}}=\frac{\mathrm{Ii}}{\mathrm{I}_{\circ}}=\alpha$

$\mathrm{V}_{\mathrm{o}}$ et Vi: output and input Voltages of the converter.

$\mathrm{I}_{\mathrm{o}}$ and Ii: output and input currents of the converter.

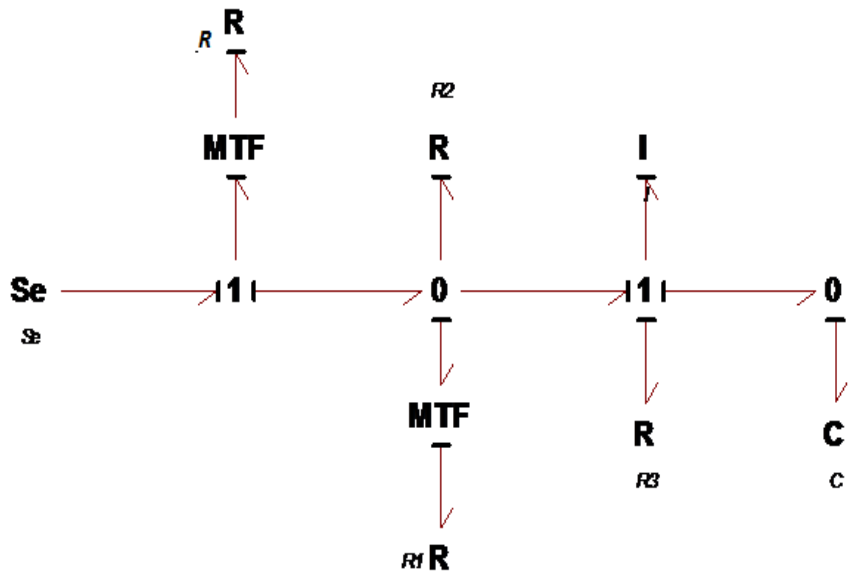

Fig. 7. Bond graph of the buck converter.

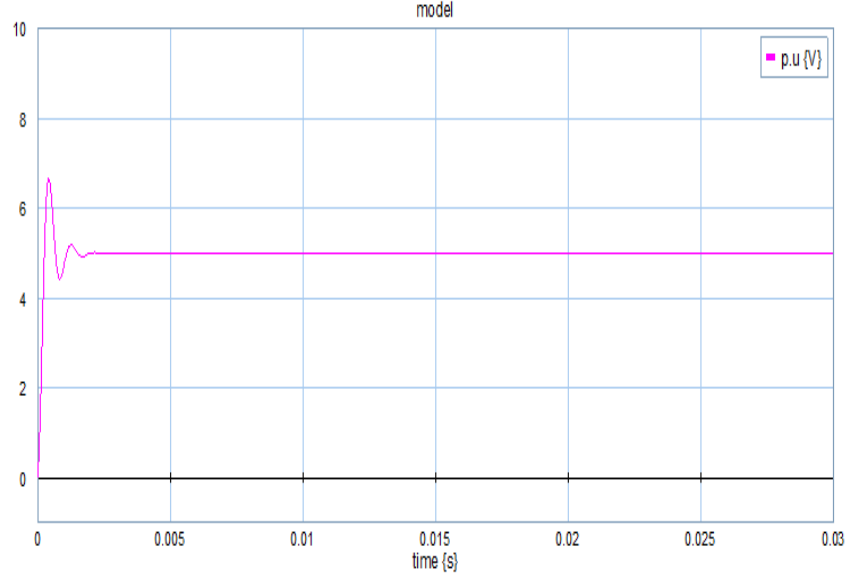

Fig. 8. Tension curve as a function of time of the buck converter.

Fig. 8 shows a simulation with $\mathrm{Se}=10 \mathrm{~V}$ while fixing a cyclic ratio $\alpha=0.5$. The voltage curve is at the input and the output of the Buck Converter as a function of time. It appears that the steady state is reached after $0.002 \mathrm{~s}$, the voltage stabilizes around the value of $5 \mathrm{~V}$ at the output of the converter.

Back to (5), we can see that the output voltage varies linearly with the duty cycle. Since the duty cycle is between 0 and 1, the output voltage Vo is always lower than the input voltage. It is for this reason that we speak of a Buck Converter.

The results describe the same evolution and the same behavior as obtained in [17] as shown in Fig. 9.

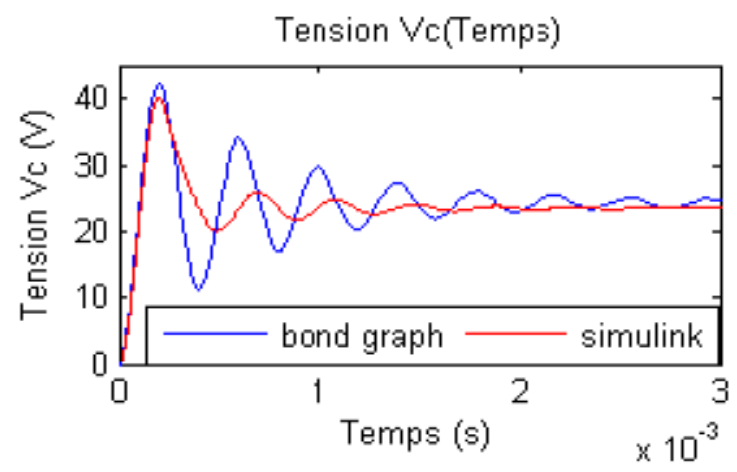

Fig. 9. Comparing BG simulation with real time simulation.

\section{3) Buck-Boost Converter}

A Buck-Boost converter is a switched-mode power supply that converts a DC voltage to a DC voltage of lower or higher value but of reverse polarity [18].

Compared to the Buck and Boost converters, the main differences are:

- The output voltage is reverse polarity to the input voltage.

- The output voltage can vary from 0 to $-\infty$ (for an ideal converter). 
Fig. 10 presents the BG model used in our simulation.

The output voltage is described by (6):

$\frac{\mathrm{V}_{\circ}}{\mathrm{Vi}}=-\frac{\alpha}{1-\alpha}$

$V i$ and ${ }_{\circ}$ : input and output Voltages.

Different types of conversion can be made by the BuckBoost converter based on the value of $\alpha$ :

- For $0<\alpha<0.5$ : The static converter is Buck and the output voltage is presented in Fig. 11.

- For $\alpha=0.5$ : The input voltage equal to the output voltage and is presented in Fig. 12.

- For $0.5<\alpha<1$ : The static converter is Boost and the output voltage is presented in Fig. 13.

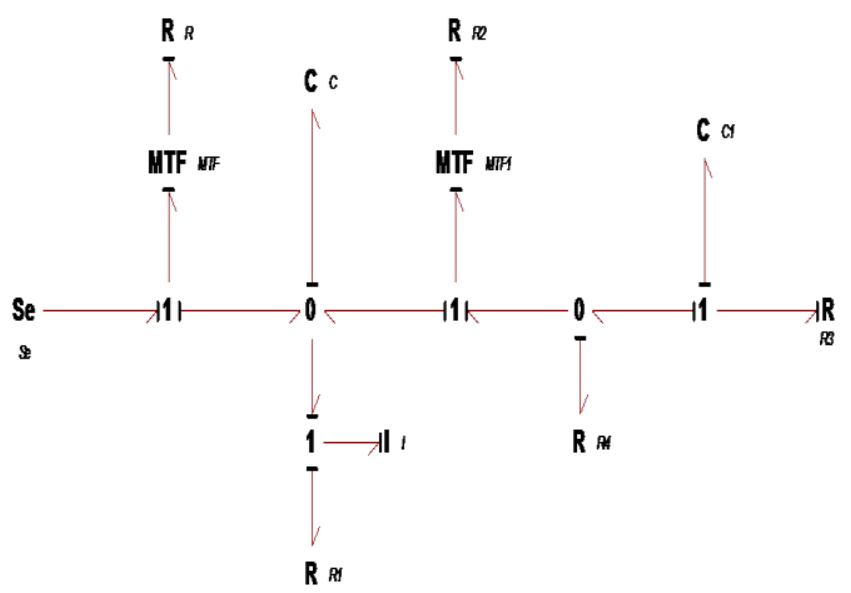

Fig. 10. BG model of a buck-boost converter.

Based on (6), we can see that the output voltage of a buckboost converter is always negative and that its absolute value increases with $\alpha$ to $\infty$ when $\alpha$ approaches 1 . The sign (-) allows the chopper function as a buck-booster. A disadvantage of this converter is that its switch does not have a terminal connected to zero, thus complicating its control.

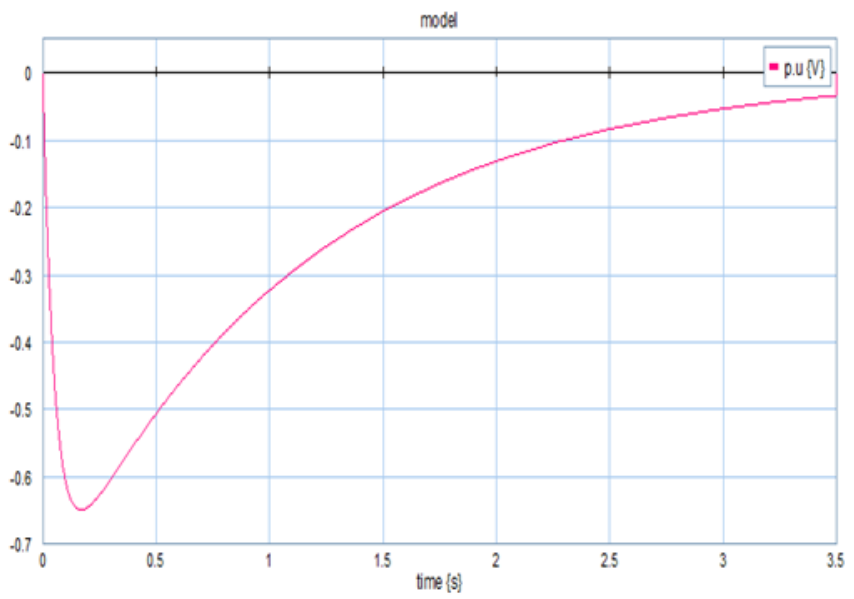

Fig. 11. Output voltage in Buck status $(0<\alpha<0.5)$.

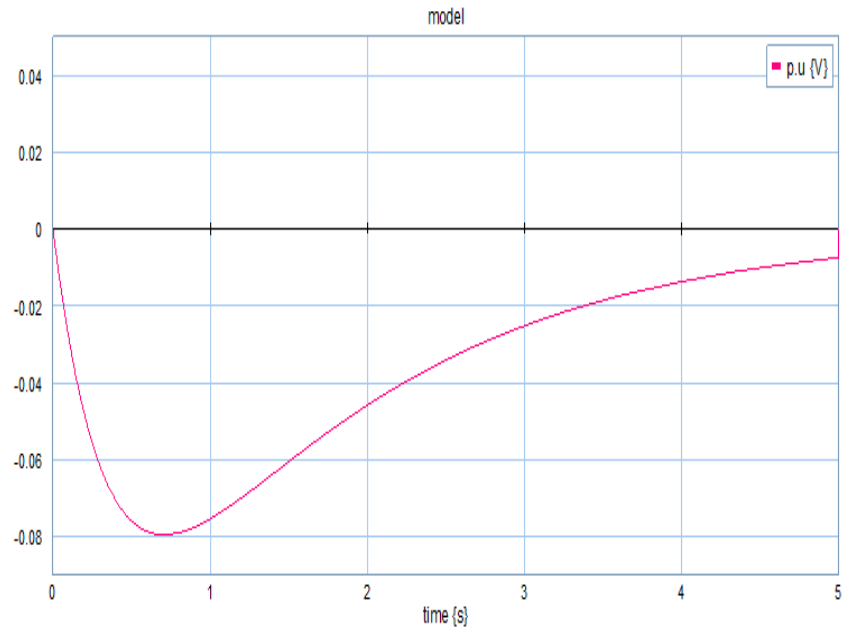

Fig. 12. Output voltage fo $\alpha=0.5 \#$.

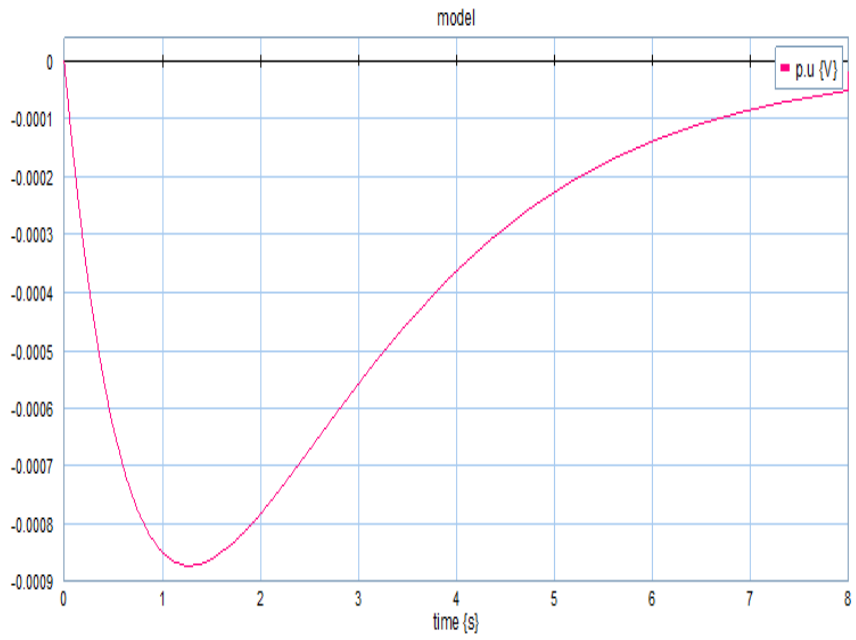

Fig. 13. Output voltage in boost operation $(0.5<\alpha<1)$.

\section{INTERACTION BETWEEN PEMFC AND STATIC CONVERTERS}

The tests were performed at a cutting frequency of $20 \mathrm{kHz}$ and any increase in frequency leads to a decrease in the speed of the simulation response, even though the curve pattern remains the same (delayed system).

\section{A. Interaction Between PEMFC and Boost Converter}

\section{1) $B G$ Model used for Simulation}

In order to study the direct connection of a static converter to a PEMFC we have carried out perturbation studies by varying the value of $\alpha$ to keep the output voltage constant and to eliminate current ripples which are parasites which have a direct influence on the efficiency and electrical performance of the fuel cell, which can cause aging (limited life).

Fig. 14 presents the global BG model of the PEMFC and the boost converter used for the next simulations. 


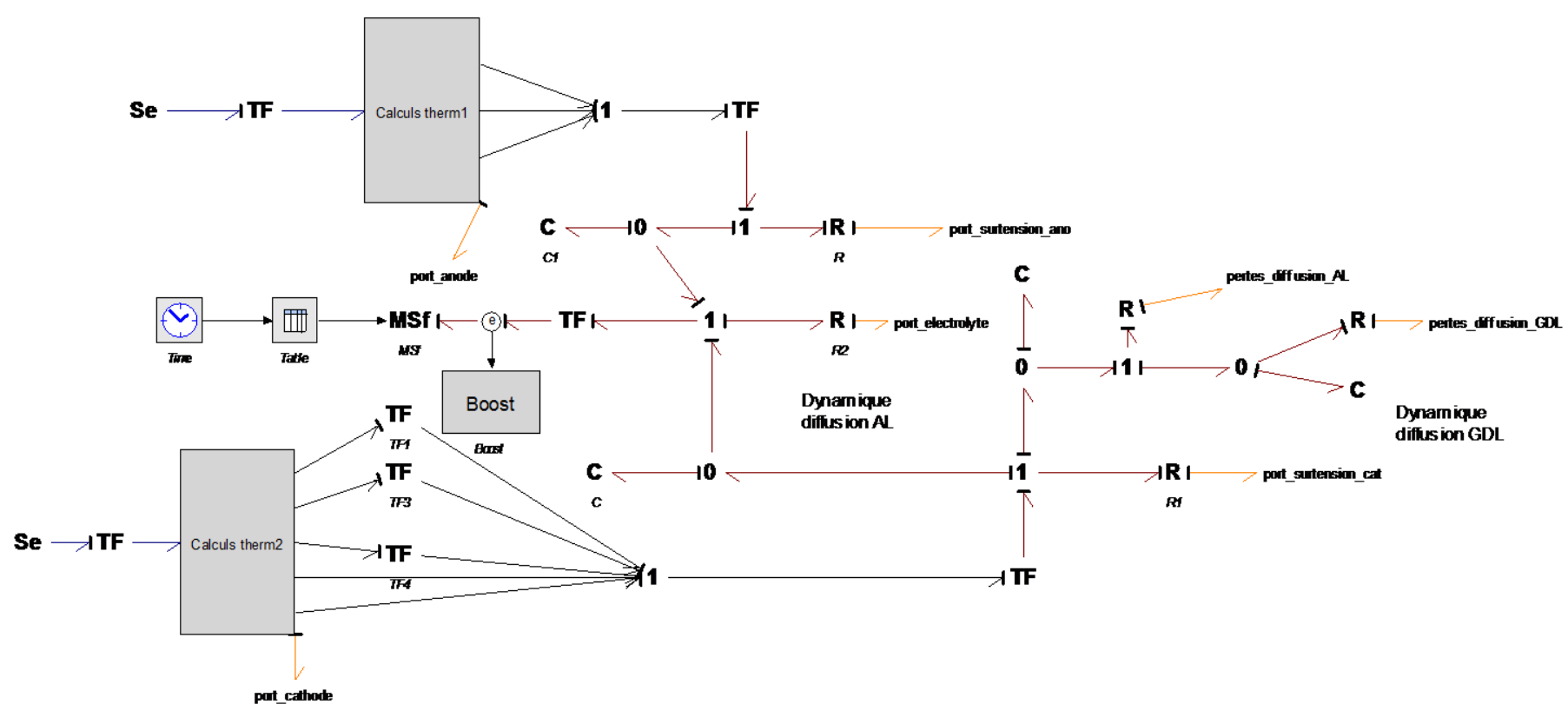

Fig. 14. BG Model of the boost converter connected to the PEMFC.

\section{2) Simulation Results and Discussion}

Fig. 15 and 16 present consecutively the output voltage and current obtained by simulating the PEMFC with the boost converter for duty cycle $\alpha$ at 0.5 and Se at $40 \mathrm{~V}$.

We notice that, at start, the voltage increases up to $110 \mathrm{~V}$ before reaching its steady state around $80 \mathrm{~V}$ at $\mathrm{t}=0.002 \mathrm{~s}$.

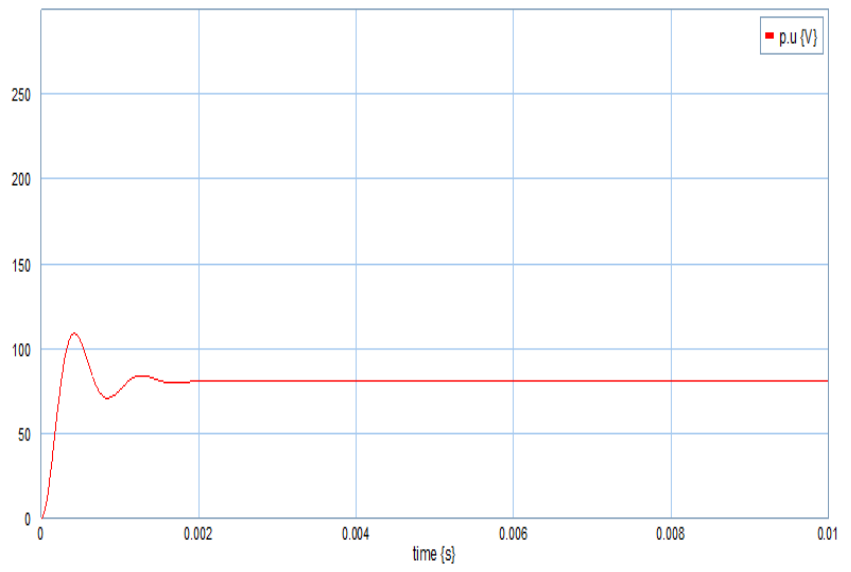

Fig. 15. Tension curve as a function of time of the PEMFC unit and boost converter $(\alpha=0.5)$.

By studying the current curve in Fig. 16, we note that the current is higher with respect to the voltage with fluctuations which negatively influences the efficiency of the cell.

This increase in current causes a local increase in temperature which can degrade the membrane [19], [20].

Fig. 17 and 18 present consecutively the output voltage and current obtained by simulating the PEMFC with the boost converter for duty cycle $\alpha$ at 0.8 and Se at $40 \mathrm{~V}$.

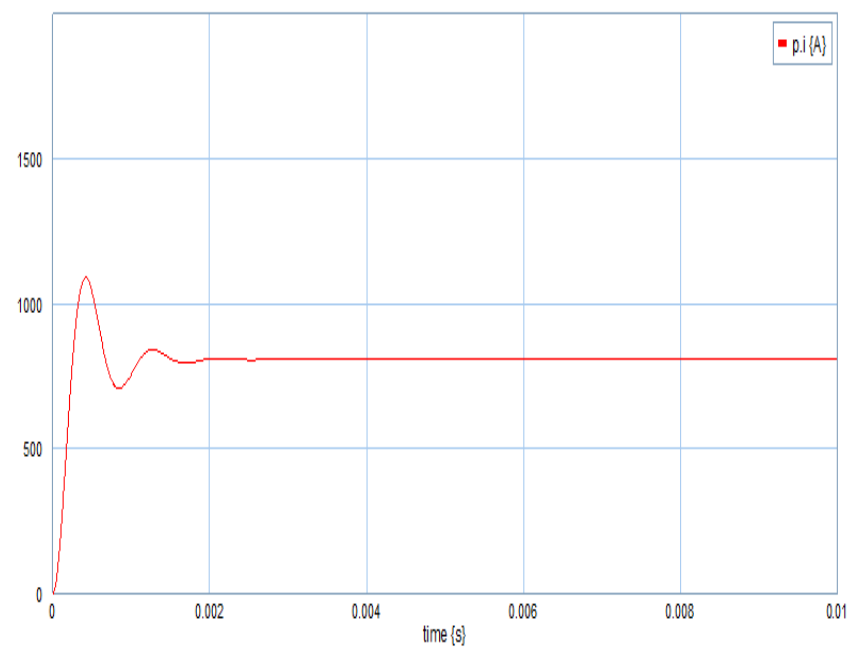

Fig. 16. Current curve as a function of time of the PEMFC unit and boost converter $(\alpha=0.5)$.

Fig. 23 shows that the obtained current when $\alpha=0.8$ is higher than the obtained current with $\alpha=0.5$. We also notice the disappear of fluctuations in both voltage and current curves (a deterioration of the disturbances) which means that increasing the value of $\alpha$ procures the elimination of current undulations.

Based on the works presented in [19]-[21], this important increase in current, in order to reach stabilization at high values, causes an increase in water generation at the cathode which is called the Diffusion Phenomenon. This phenomenon might cause a high level of water at both anode and cathode sides if the evacuation process of the water is not properly managed, this will eventually cause the so-called flooding. 


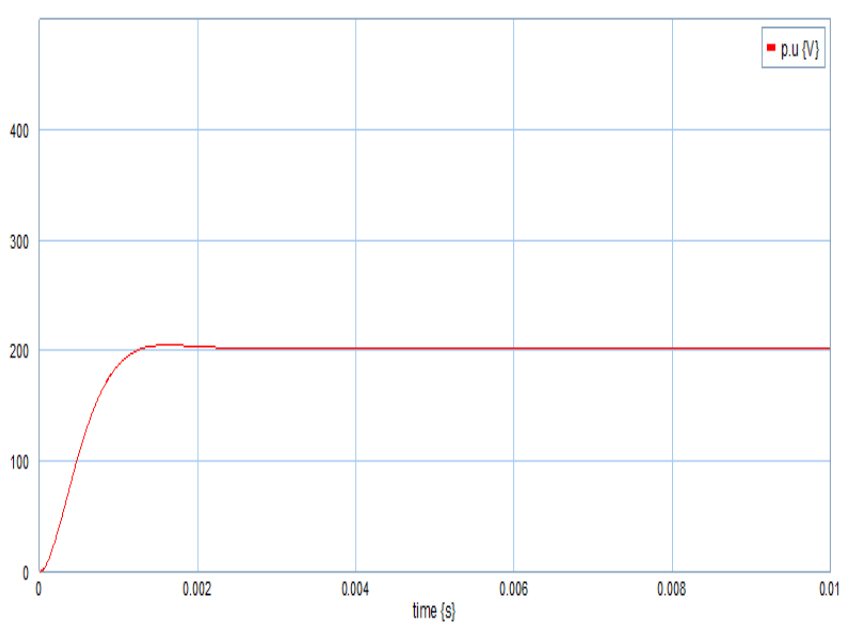

Fig. 17. Output voltage curve $\alpha=0.8$.

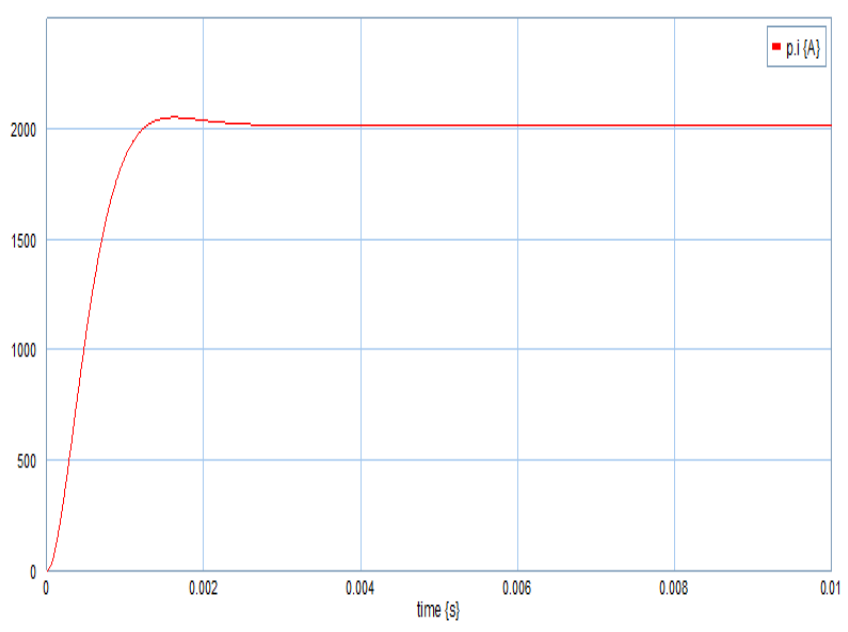

Fig. 18. Output current curve for $\alpha=0.8$.

We conclude that the stack's operating temperature has an important influence on flooding conditions. Thus, permanent degradation of the stack performance can be resulted by the influence of bad water management.

Note: It is the double layer capacitor which fixes the dynamics of the diffusion phenomenon in the activation layer [22].

In the case of a boost Converter, according to fonts [22] and as shown in Fig. 19, the losses of the membrane are proportional to the current ripple $\Delta \mathrm{i}$. The ripple of $200 \%$ of the average value increases by $33 \%$ of the losses in the membrane. On the other hand, a $20 \%$ ripple increases only $0.33 \%$ of the losses in the membrane.

\section{B. Interaction Between PEMFC and Buck Converter}

\section{1) BG Model used for Simulation}

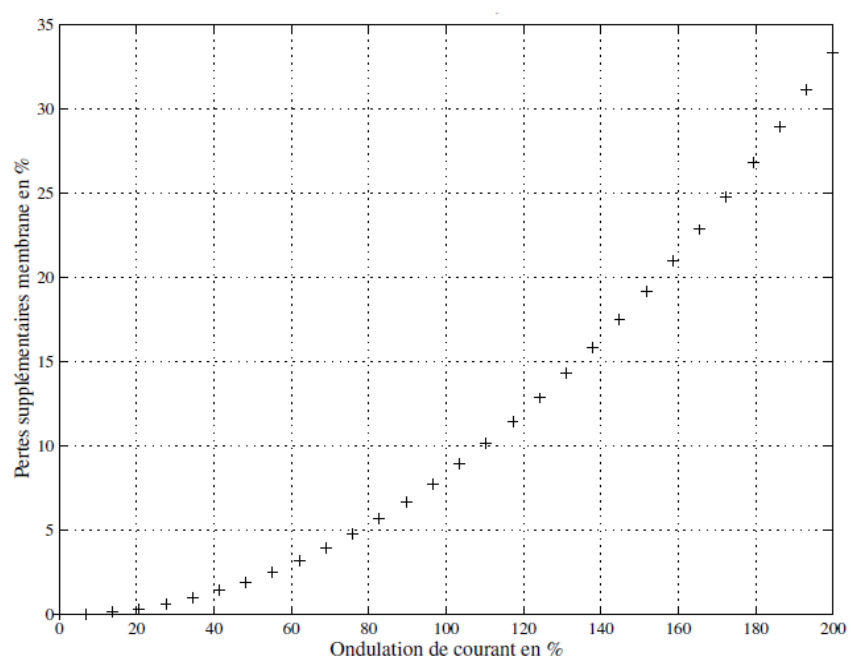

Fig. 19. Additional losses in the membrane as a function of the amplitude of the current ripple.

Fig. 20 presents the global BG model of the PEMFC connected to the Buck converter used for the next simulations to investigate the interconnections between them for different values of $\alpha$.

\section{2) Simulation results and discussion}

Fig. 21 and 22 present consecutively the output voltage and current obtained by simulating the PEMFC with the Buck converter for duty cycle $\alpha$ at 0.2 and Se at $40 \mathrm{~V}$.

The simulation of the PEMFC system with the Buck Converter shows an increase, without any fluctuations or disturbances, in voltage value to reach the $20 \mathrm{v}$ steady state.

The role of the diode can be demonstrated in this simulation by the sudden decrease of the current (drop of current) after the important increase in the beginning of the simulation.

- From 0 to $\alpha \mathrm{T}$ : the current increases through the switch $\mathrm{S}$ by closing it.

- The voltage source is the origin of energy during this phase.

- From $\alpha \mathrm{T}$ to $\mathrm{T}$ : the current decreases through the diode $D$ by opening the switch $S$.

This is the "freewheel" phase due to the freewheeling diode. The purpose of these diodes is to prevent the occurrence of surges and sudden variations in intensity (essentially at break) [23].

Note: Current ripple $\Delta \mathrm{i}$ decreases when $\mathrm{L}$ increases (smoothing). 


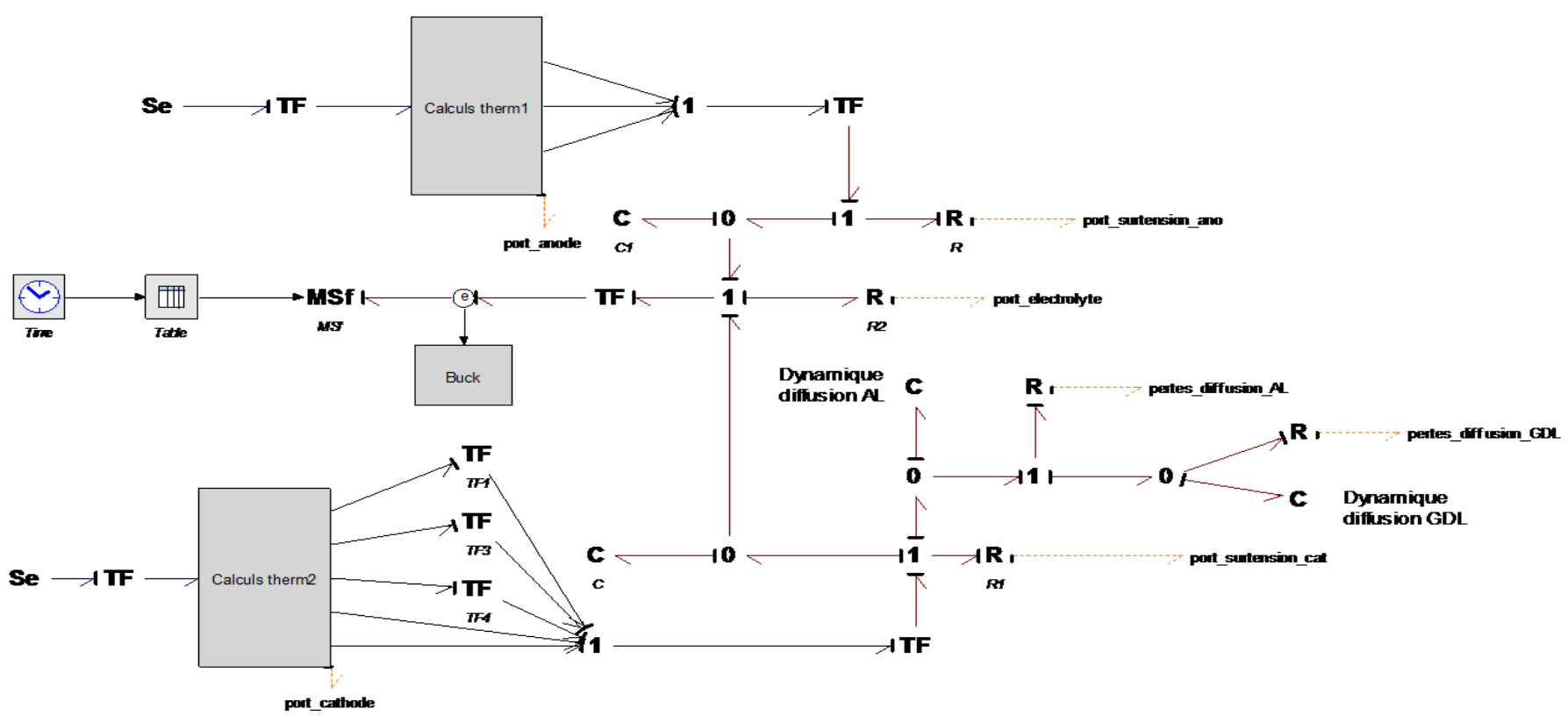

Fig. 20. BG model used for simulation of PEMFC connected to Buck converter.

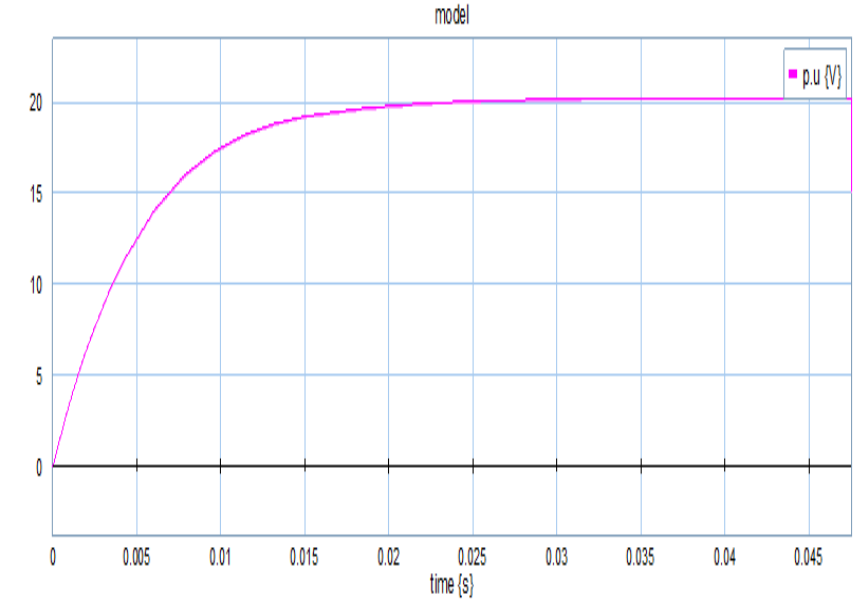

Fig. 21. Output voltage curve for $\alpha=0.2$.

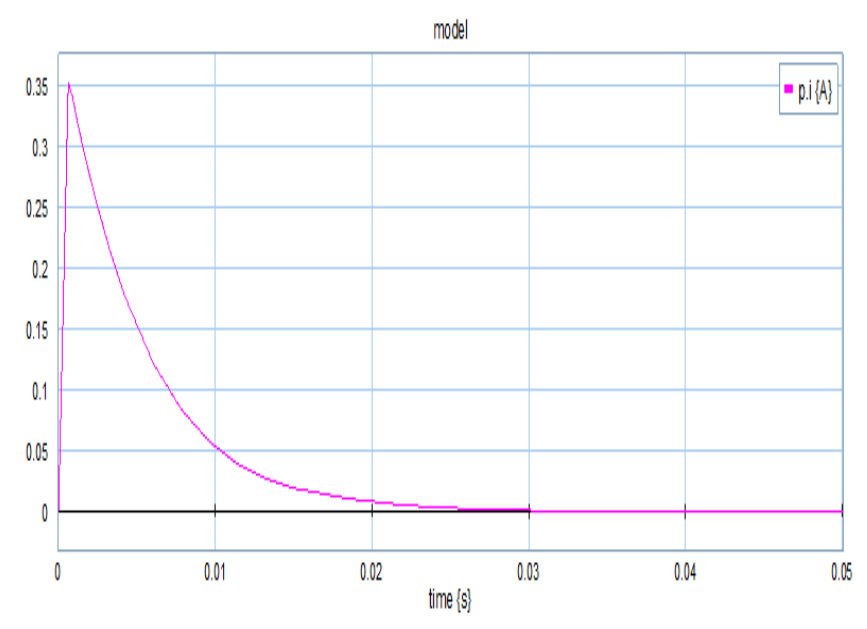

Fig. 22. Output current curve for $\alpha=0.2$.

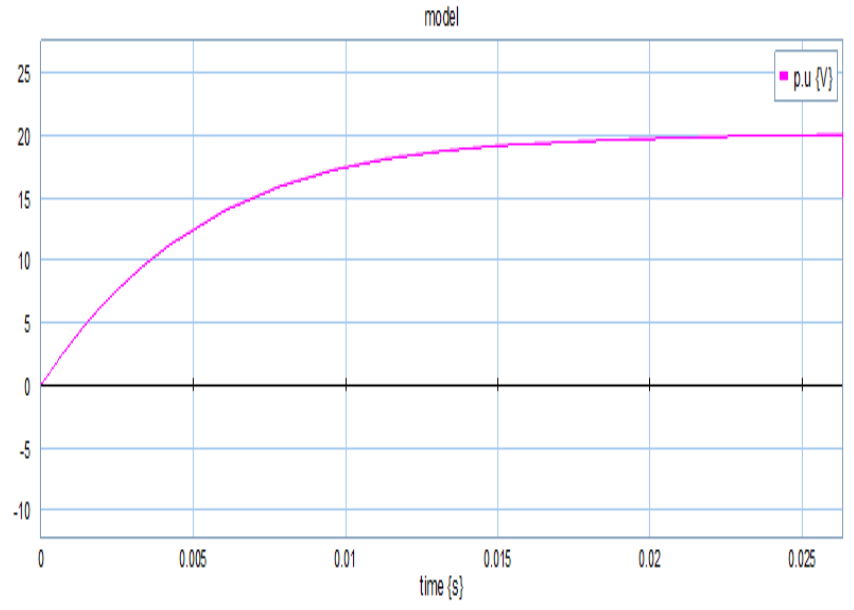

Fig. 23. Output voltage curve for $\alpha=0.8$.

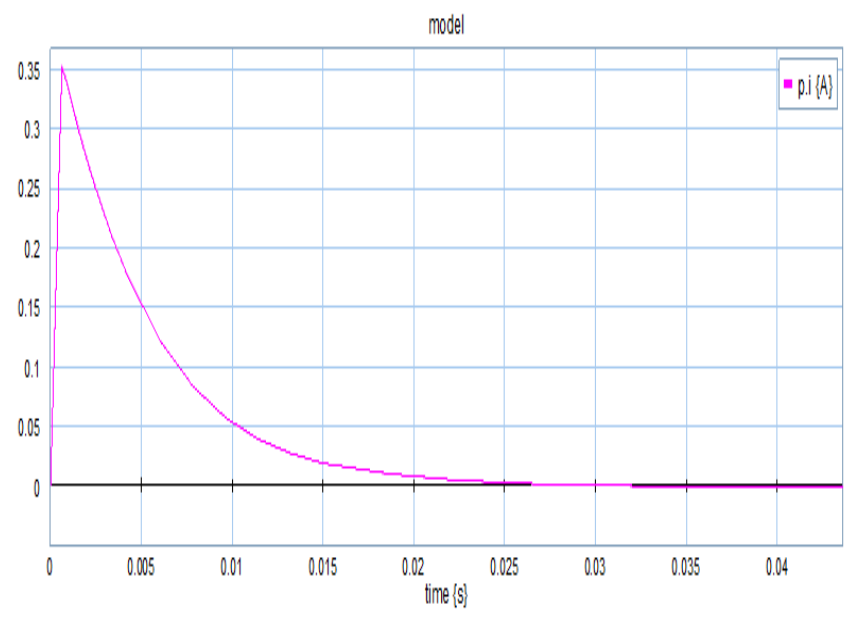

Fig. 24. Output current curve for $\alpha=0.8$. 
Fig. 23 and 24 present consecutively the output voltage and current obtained by simulating the PEMFC with the Buck converter for duty cycle $\alpha$ at 0.8 and Se at $40 \mathrm{~V}$.

The obtained results at both values of $\alpha, 0.2$ and 0.8 , are similar which proves the filtering of high frequency harmonics has been efficiently done by the double layer capacitor.

The generated undulations by the buck converter are more restrictive than those generated by the boost one.

Among the high frequency corrugations, those generated by The Buck converters are more constraining than those generated by the boost converters. This proves that the Buck converter generates more losses, shown in Fig. 25, in the PEMFC performance more than the Boost converter as a consequence of the additional generated ripples [22].

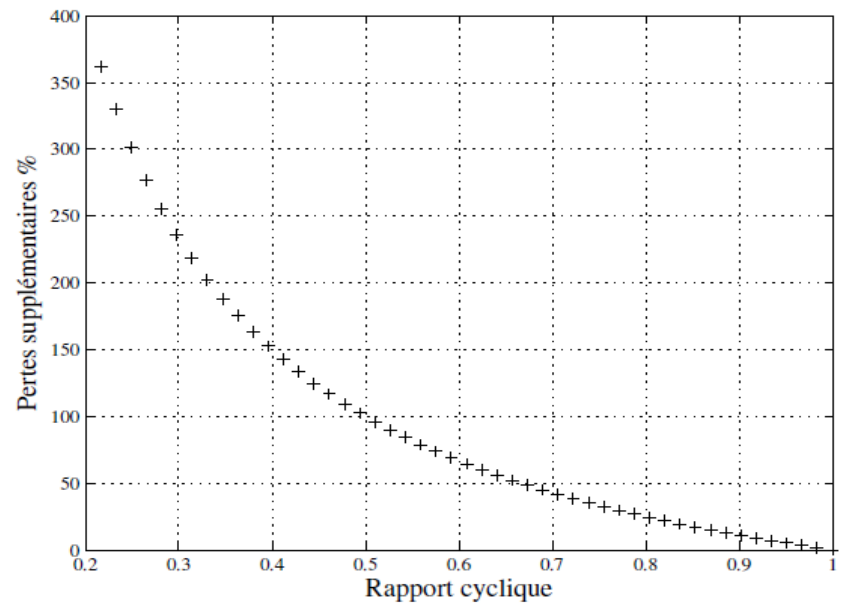

Fig. 25. Additional losses in the membrane as a function of duty cycle.

We can ask the question about the aging of the battery and the membrane which results in a reduction in electrical performance.

\section{Interaction Between PEMFC and Buck-Boost Converter}

\section{1) Operating as Buck Converter}

Fig. 26 and 27 present the curves of voltage and current at the output of the buck-boost converter obtained by imposing a value of $\alpha=0.1$.

We notice a decrease in current to -35A and in voltage to $35 \mathrm{~V}$, the steady state is reached after $2 \mathrm{~s}$.

Fig. 28 and 29 present the curves of voltage and current at the output of the buck-boost converter obtained by imposing a value of $\alpha=0.4$.

By increasing the value of $\alpha$, the current and voltage decrease compared to their values for $\alpha=0.1$. We can see that the undulations of the current and the voltage decrease when $\alpha$ increases.

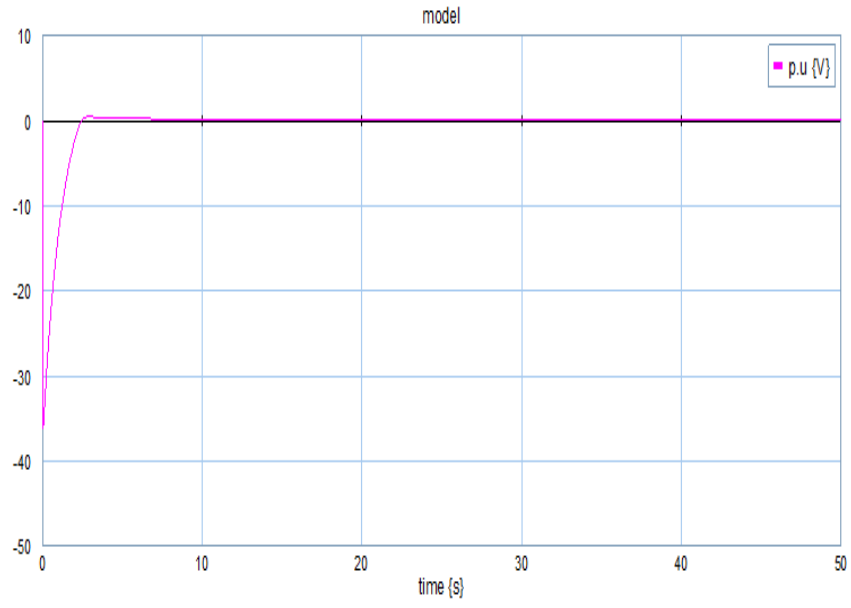

Fig. 26. Voltage curve for $\alpha=0.1$.

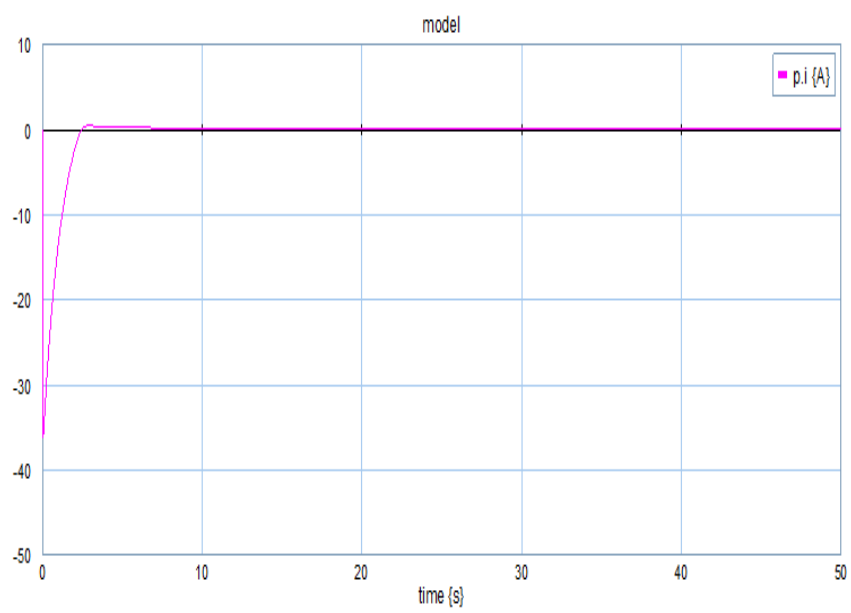

Fig. 27. Current curve for $\alpha=0.1$.

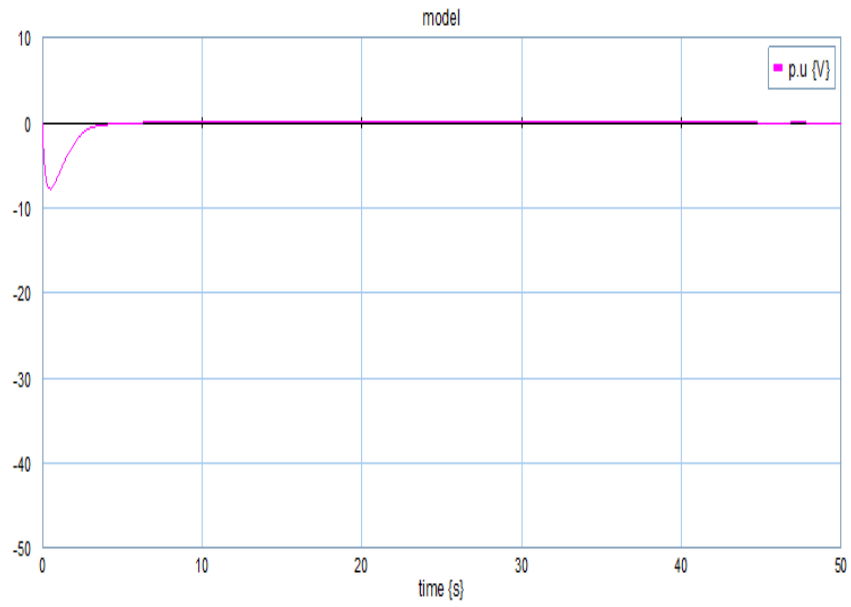

Fig. 28. Voltage curve for $\alpha=0.4$. 


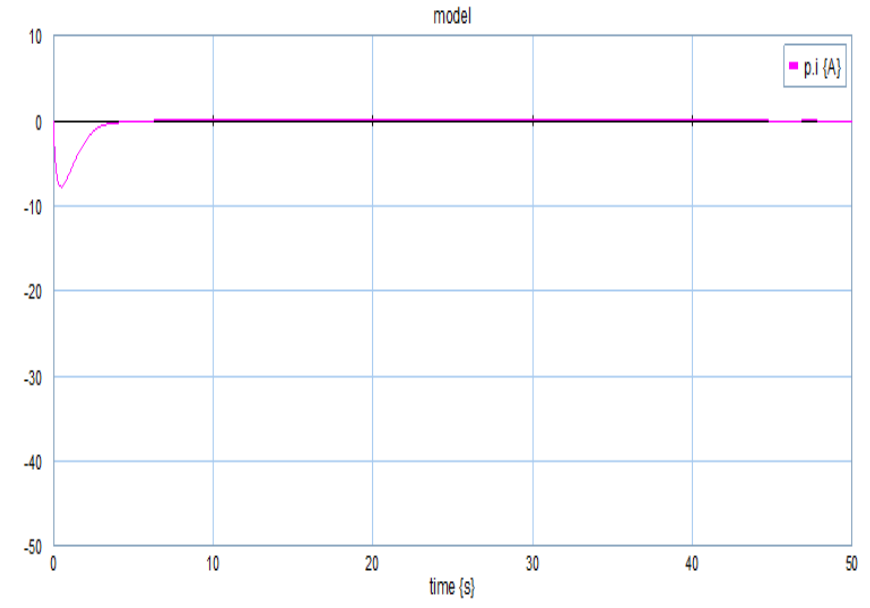

Fig. 29. Current curve for $\alpha=0.4$.

\section{2) Operating as Boost converter}

Fig. 30 present the curve of current at the output of the buck-boost converter obtained by imposing a value of $\alpha=0.6$ and Fig. 31 and 32 present, respectively the curves of voltage and current at the output of the buck-boost converter obtained by imposing a value of $\alpha=0.8$.

After the simulation, we note from Fig. 31 and 32 that the output current and the voltage are zero, so the Fuel Cell and the Buck-Boost Converter system is no longer functional from $\alpha=0.8$.

We have noticed from the preceding figures that each time when we simulate the Fuel Cell system with the Buck-Boost Converter, the voltage and the current abruptly decrease at the instant ' 0 ' and then increase and return to its state of "Balance" due to its switch which does not have a terminal connected to the zero, thus complicating its control.

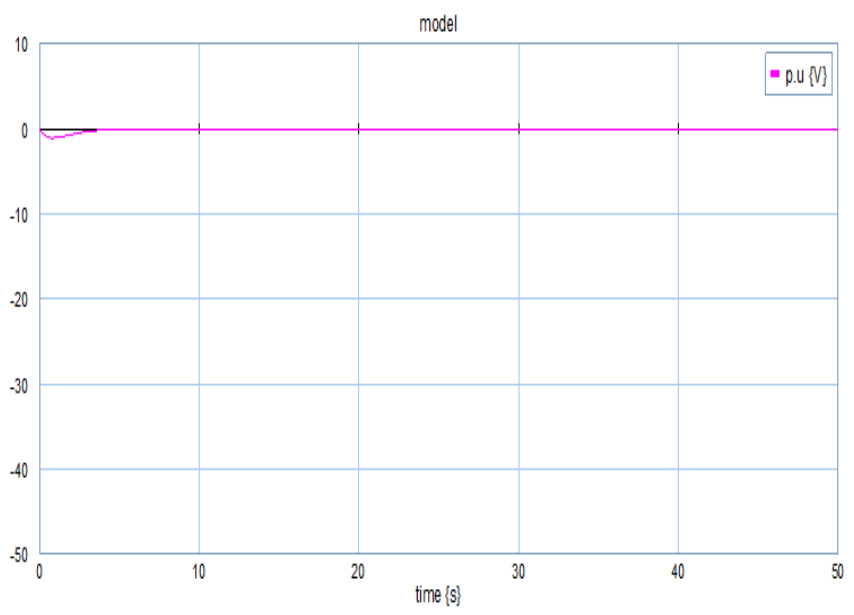

Fig. 30. Current curve for $\alpha=0.6$.

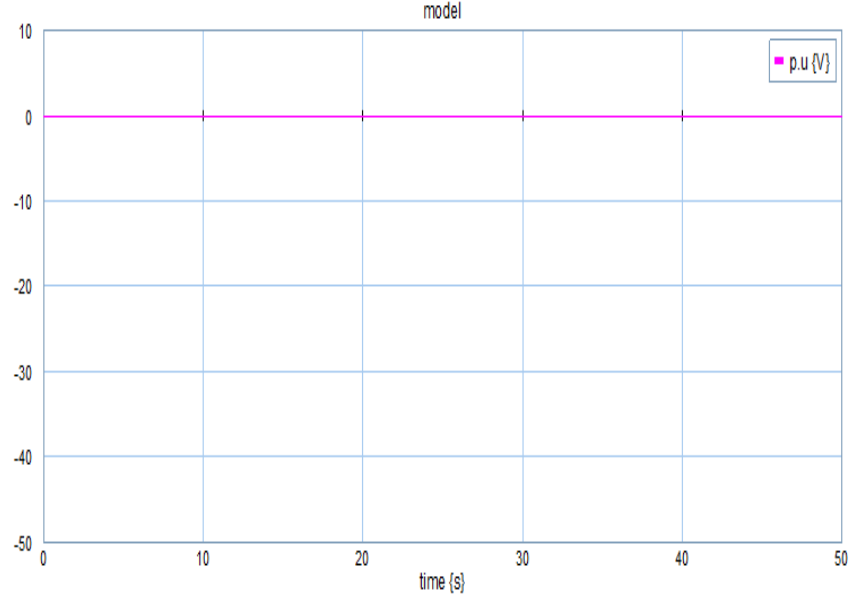

Fig. 31. Voltage curve for $\alpha=0.8$.

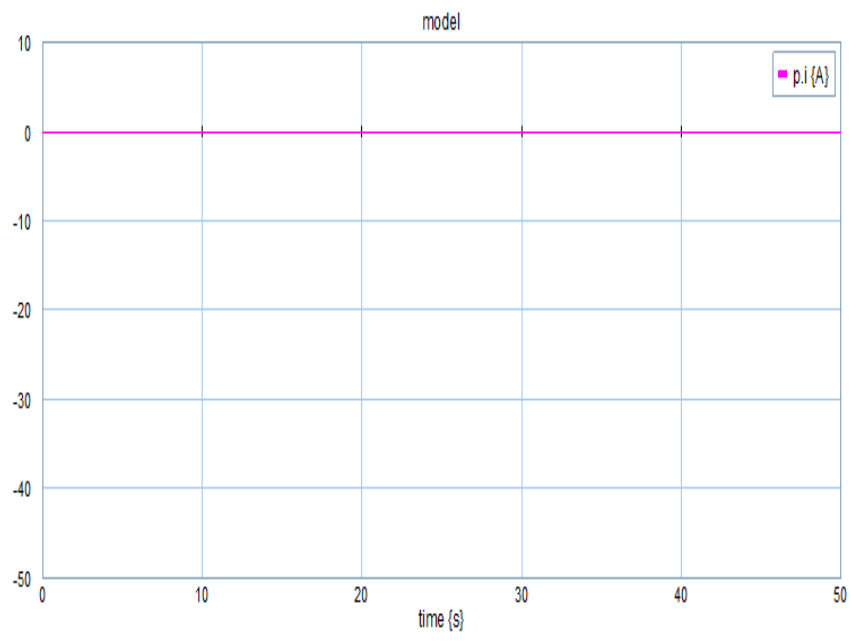

Fig. 32. Current curve for $\alpha=0.8$.

\section{CONCLUSION}

The obtained results showed that using a Buck converter shows important disturbances and undulations in the output voltage and current than the other two converters. Also, a Buck-Boost converter makes the control of the PEMFC more complicated. With using a Boost converter, we are risking to have the diffusion phenomenon if the water evacuation process is not well done.

As future work, we would be interested in investigating different interactions between the PEMFC and more advanced topologies of DC-DC converters such as the Sepic converter which presents the possibility of both buck and boost operations like the Buck-Boost converter but with the advantage of keeping the same polarity in the output. 


\section{REFERENCES}

[1] BENCHOUIA Nedjem Eddine, HADJADJ AOUL Elias, LAKHDAR Khochemane and BOUZIANE Mahmah, "Bond graph modeling approach development for fuel cell PEMFC systems", International Journal of Hydrogen Energy, 39(27), pp. 15224-15231, 2014. https://doi.org/10.1016/j.ijhydene.2014.05.034.

[2] A.R. Maher, AL-BAGHDADIL Sadiq, "Modelling of Proton Exchange Membrane Fuel Cell Performance Based on Semi-Empirical Equations", Renewable Energy, 30(10), pp. $1587 \quad$ - 1599, 2005. https://doi.org/10.1016/j.renene.2004.11.015

[3] CHAN C. C. , BOUSCAYROL Alain and CHEN Keyu, "Electric, Hybrid, and Fuel-Cell Vehicles: Architectures and Modeling”, IEEE Transactions on Vehicular Technology, 59(2), pp. 589-598, 2010. http://dx.doi.org/10.1109/TVT.2009.2033605

[4] ANDARI Wahib, GHOZZI Samir, ALLAGUI Hatem and MAMI Abdelkader, "Design, Modeling and Energy Management of a PEM Fuel Cell / Supercapacitor Hybrid Vehicle", International Journal of Advanced Computer Science and Applications(IJACSA), 8(1), 2017. http://dx.doi.org/10.14569/IJACSA.2017.080135

[5] CHAOUALI Houssem ; OTHMANI Hichem; MEZGHANI Dhafer and MAMI Abdelkader, "Enhancing classic IFOC with Fuzzy Logic technique for speed control of a 3 Ebara Pra-50 moto-pump", IEEE 17th International Conference on Sciences and Techniques of Automatic Control and Computer Engineering(STA), Tunisia 2016. http://dx.doi.org/10.1109/STA.2016.7951985

[6] X. Roboam, and G. Gandanegara, "Causal Bond Graph of Unbalanced Multi-phase Electrical Systems". International Conference on Integrated Modeling \& Analysis in Applied Control \& Automation(IMAACA), Italy 2004.

[7] MEZGHANI Dhafer, OTHMANI Hichem, SASSI Fares, MAMI Abdelkader and DAUPHIN-TANGUY Geneviève, "A New Optimum Frequency Controller of Hybrid Pumping System: Bond Graph Modeling-Simulation and Practice with ARDUINO Board" International Journal of Advanced Computer Science and Applications(IJACSA), 8(1), 2017.

http://dx.doi.org/10.14569/IJACSA.2017.080112

[8] SUEUR C., "Bond-graph approach for structural analysis of MIMO linear systems", Journal of the Franklin Institute, 328(1), pp. 55-70, 1991. https://doi.org/10.1016/0016-0032(91)90006-O

[9] FILIPPA M., MI C., SHEN J. and STEVENSON R., "Modeling of a hybrid electric vehicle test cell using bond graphs", IEEE Transactions on Vehicular Technology, 54(3), pp. 837-845, 2005. http://dx.doi.org/ 10.1109/TVT.2005.847226.

[10] WENZHONG GAO David, MI Chris, EMADI Ali, "Modeling and Simulation of Electric and Hybrid Vehicles", Proceedings of the IEEE, 95(4), pp. 729-745, 2007.

http://dx.doi.org/10.1109/JPROC.2006.890127

[11] SAISSET Rémi , FONTES Guillaume, TURPIN Christophe, ASTIER Stéphan, "Bond Graph model of a PEM fuel cell", Journal of Power Sources, 156(1), pp. 100-107, 2006.

https://doi.org/10.1016/j.jpowsour.2005.08.040

[12] J. GRANDA Jose, "The role of bond graph modeling and simulation in mechatronics systems: An integrated software tool: CAMP-G,
MATLAB-SIMULINK, Mechatronics", 12(9-10), pp. 1271-1295, 2002. https://doi.org/10.1016/S0957-4158(02)00029-6

[13] BELHADJ J., "Modeling, Control and Analyze of Multi-Machine Drive Systems using Bond Graph Technique", Journal of Electrical Systems(JES), 2(1), pp.29-51, 2006.

[14] PERAZA César, GREGORIO DIAZ Jose, J. ARTEAGA-BRAVO Francisco, VILLANUEVA Carlos and GONZALEZ-LONGATT Francisco, "Modeling and Simulation of PEM Fuel Cell with Bond Graph and 20sim", IEEE American Control Conference(ACC), USA 2008. http://dx.doi.org/10.1109/ACC.2008.4587303

[15] BEN SALEM W., MZOUGHI D., ALlAGUI H. and MAMI A., The bond graphs to the study of interactions between the PEM fuel cell and static converters", IEEE 17th International Conference on Sciences and Techniques of Automatic Control and Computer Engineering(STA), Tunisia 2016. http://dx.doi.org/10.1109/STA.2016.7952004

[16] Mohamed Akram JABALLAH, Dhafer MEZGHANI and Abdelkader MAMI, "Design and Simulation of Robust Controllers for Power Electronic Converters used in New Energy Architecture for a (PVG)/ (WTG) Hybrid System" International Journal of Advanced Computer Science and Applications(IJACSA), 8(5), 2017. http://dx.doi.org/10.14569/IJACSA.2017.080531

[17] BOUDJEMAÂ Mehimmedetsi, "Application du Formalisme Bond Graph à une chaine de conversion d'Energie Photovoltaique", $\mathrm{Ph} . \mathrm{D}$ Thesis, Ecole Doctorale: Sciences pour l'ingénieur et microtechniques, 2006.

[18] ALAM Aftab, TAO Lei and HABIB Kashif, "Optimal model predictive control for disturbance rejection and stability in buck-boost converter and its comparison with classical technique", IEEE International Conference on Power System Technology (POWERCON), 2016 Australia. http://dx.doi.org/10.1109/POWERCON.2016.7753946

[19] E. FRAPPÉ, “Architecture de convertisseur statique tolérante aux pannes pour générateur pile à combustible modulaire de puissancetraction 30Kw". Ph.D Thesis, L'Institut français des sciences et technologies des transports, de l'aménagement et des réseaux (IFSTTAR-LTN) Et du Laboratoire de génie électrique de Paris (LGEP), 2012.

[20] N. Yousfi-Steiner, Ph. Mocoteguy, D. Candusso, D. Hissel, A. Hernandez, A. Aslanides, "A review on PEM voltage degradation associated with water management: Impacts, influent factors and characterization", journal of power sources, 183(1), pp. 260-274, 2008. https://doi.org/10.1016/j.jpowsour.2008.04.037

[21] Thibaut Colinart, Dylan Lelièvre, Patrick Glouannec, «Influence de l'hystérésis sur le comportement hygrothermique d'un enduit de finition intérieure biosourcé », Conférence IBPSA, France 2014.

[22] FONTÉS Guillaum, "Modélisation et caractérisation de la pile PEM pour l'étude des interactions avec les convertisseurs statiques", $\mathrm{Ph} . \mathrm{D}$ Thesis, l'ENSEEIHT UMR, 2005.

[23] Zongqi Hu, Dongsheng Ma, "A pseudo-CCM buck converter with freewheel switching control", IEEE International Symposium on Circuits and Systems(ISCAS), Japan 2005. http://dx.doi.org/10.1109/ISCAS.2005.1465279 